\title{
КРИТЕРІЇ ТА ПОКАЗНИКИ ЕКСПЕРИМЕНТАЛЬНОГО ВИВЧЕННЯ СТАНУ ЕСТЕТИЧНОЇ ВИХОВАНОСТІ СТАРШОКЛАСНИКІВ
}

\author{
У статті визначено критеріі та показники для експериментального вивчення стану естетичної вихованості \\ старшокласників у загальноосвітній школі, а також наведено рівні естетичної вихованості, розроблені на основі \\ співвіднесення критеріїв. \\ Ключові слова: естетичне виховання, критерії естетичної вихованості, показники, рівні естетичної вихованості. \\ В статье определены критерии и показатели для экспериментального изучения состояния эстетической \\ воспитанности стариеклассников, разработанной на основе соотношения критериев. \\ Ключевые слова: эстетическое воспитание, критерии эстетической воспитанности, показатели, уровни эстетической \\ воспитанности.
}

The criteria and indicators for the experimental study of aesthetic breeding of high school pupils in secondary school are defined in the article. The author also describes the levels of aesthetic breeding, based on the correlation of criteria.

Key words: aesthetic breeding, the criteria of esthetical education, indicators, the levels of aesthetic breeding.

Сучасний рівень розвитку науки і суспільства в Україні висуває нові вимоги до громадянина як суб'єкта суспільної діяльності. Тому основним завданням школи нині $є$ не тільки забезпечення учнів фундаментальними знаннями 3 різних дисциплін, а також формування сприятливого середовища, у якому культурно-наукові знання, одержані учнями, зроблять свій внесок у саморозвиток особистості та стануть невід'ємною частиною естетичної культури сучасної людини. Тому передовсім постає необхідність естетизації освіти й культуротворчого формування особистості учня.

Беручи за основу сформовану практику виховної роботи, зазвичай виокремлюють такі структурні компоненти естетичного виховання: естетична освіта, яка закладає теоретичні та ціннісні основи естетичної культури особистості; художнє виховання в його освітньо-теоретичному і художньопрактичному вияві, що формує художню культуру особистості у єдності навичок, знань, ціннісних орієнтацій, смаків; естетична самоосвіта і самовиховання, зорієнтовані на самовдосконалення особистості; виховання творчих потреб і здібностей [10, с. 230].

Домінантою естетичної культури особистості є іiї художня культура, рівень якої залежить від міри художньої освіченості, широти інтересів у сфері мистецтва, глибини його розуміння і розвиненої здатності адекватної оцінки художніх переваг естетичних об'єктів.

На думку дослідників, критеріями естетичної вихованості $\epsilon$ : естетична сприйнятливість; фактичний рівень освіченості в галузі культури; наявність естетичного ідеалу; уявлення про досконалість у мистецтві й дійсності; художній смак; здатність адекватного відтворення в уяві художніх образів; розвинена здатність милуватися красою; загальна здатність до глибокого переживання почуттів; здатність естетичного судження; здатність до художньо-естетичної творчості в мистецтві і житті, поведінці, стосунках [8, с. 270-271].

Meта статmi - висвітлити й описати розроблені нами власні критерії та показники естетичної вихованості старшокласника, їх змістовну наповненість, вияви і методи визначення для проведення констатувального експерименту і подальшої систематичної діагностики рівня розвитку естетичних якостей i естетичної культури особистості загалом, які дозволять ефективніше здійснювати диференційоване і особистісно зорієнтоване навчання й виховання.

До критеріїв, на основі яких можливе визначення рівня і динаміки естетичної вихованості, пропонуємо віднести такі: гносеологічний, гедоністичний, критерій культурного естетичного самовизначення, критерій готовності до міжкультурного діалогу.

Гносеологічний критерій відображає чуттєво-емоційне й інтелектуальне ставлення особи до дійсності та мистецтва, яке супроводжується відповідною реакцією, естетичним відчуттям, що характеризується: адекватністю сприйняття матеріалу, стійкістю, особливістю взаємозв'язку емоційного і інтелектуального. При тому варто акцентувати увагу на адекватності відчуття особливостям твору мистецтва,що значною мірою визначається не лише психологічними якостями особистості, а й рівнем іiі естетичної освіченості. В естетичному розвитку особистості, як зазначає В. Липський, «точкою відліку» $є$ певний рівень естетичної інформованості [7, с. 63].

На основі отриманих знань і розвитку здібностей художнього й естетичного сприйняття соціально-психологічних якостей людини забезпечується змога емоційного переживання та оцінювання естетично значущих предметів і явищ [3].

Розглядаючи естетичне виховання як специфічний спосіб розвитку «інтелектуальної орієнтації», вважаємо за доречне зазначити, гносеологічний критерій сприяєтиме цілісному оволодінню на індивідуальному рівні особливостей культури, розумінню єдності та стилістичної спорідненості, що $є$ необхідною передумовою її теоретичного пізнання.

Основними показниками окресленого критерію $\epsilon$ : 
- уявлення про культуру як соціальний феномен, сформованість естетичного усвідомлення світу;

- $\quad$ володіння значеннями базових понять, фактажем культурних явищ та методами аналізу;

- здатність до виявлення стрижневих стильових епохальних особливостей культурних явищ;

- перспектива здійсненні можливість здійснювати філософсько-теоретичного аналізу культур, виявлення закономірностей у художньому розвитку людства;

- розуміння культурних універсалій, відмінностей та типовості різних культур;

- естетична зумовленість творчого розв'язання емоційно-образних питань і завдань; незалежність художньо-естетичних міркувань;

- естетичне осмислення поведінки (пріоритет дій, заснованих на прагненні до порядку i творенні прекрасного);

- рівень вербального тезаурусу.

Гедоністичний критерій відображає здатність до переживання естетичної насолоди від спілкування з мистецтвом і творчістю, розуміння мистецтва як засобу художнього спілкування, що забезпечує здійснення емоційно-інтелектуального зв'язку між авторами художніх творів і школярами крізь опосередковану ланку - естетичний об'єкт. У процесі сприйняття інформації встановлюється духовний зв'язок школяра 3 естетичним об'єктом, заснований на безкорисливому інтересі до останнього і супроводжуваний відчуттям глибокої насолоди від спілкування 3 ним.

Гедоністична функція (або естетична, як іï визначає Ю. Борев) мистецтва має декілька планів джерел буття в художньому творі. Вони є гарантом тієї насолоди, яку відчуває людина під час сприйняття високих зразків мистецтва [1].

Гедоністична функція мистецтва визначає його специфічну, нічим незамінну, здатність формувати естетичні смаки, здібності й потреби людини, а також пробуджувати творчий дух, творче начало особистості. Ю. Борев стверджує, що саме ця функція примушує людину освоювати світ за законами краси [1].

Гедоністичний ефект естетичного виховання полягає в тому, що формування особистості старшокласника повинно протікати у формі переживання естетичної насолоди, що робить цей процес не лише ненав'язливим, мимовільним, але і позитивним.

Гедоністичний критерій безпосередньо зумовлено тим, що мистецтво поєднує не лише художню, але і специфічно естетичну інформацію. Тому радість зіткнення 3 ним є своєрідним емоційним усвідомленням причетності до творчого акту, здатністю уявного доручення до великої таїни творчості. Переживання естетичної насолоди не лише залучає учнів до пізнавального та ідейного змісту естетичного об'єкта, але в той же час формує творчі здібності, підвищує творчий потенціал, удосконалюючи особистість, формуючи ціннісну свідомість, учить бачити життя крізь призму образності. Це відчуття естетичної значущості навколишнього життя дає школярам ціннісні орієнтації у світі.

Гедоністичний критерій - це прояв самоцінного значення дитини. Саме самоцінна особистість $\epsilon$ найбільш соціально дієвою. Іншими словами, самоцінність людини - істотна сторона іiі соціалізації, чинник творчої активності [9].

Основними показниками його є:

- переживання радості від залучення до творчості, що дає змогу відчути співпереживання, співтворчість; життя;

- сприйняття життя крізь призму образності, відчуття естетичної значущості навколишнього

- засвоєння конкретно-чуттєвого багатства світу, розуміння його естетичного розмаїття;

- здатність оцінювати естетичні явища дійсності та мистецтва (гармонії форми і змісту) 3 позицій гуманістичного естетичного ідеалу; адекватності оцінки якості естетичного об'єкта;

- участь у ціннісно-орієнтованій діяльності, залучення до процесу художньої творчості;

- $\quad$ виявлення самоцінності особистості.

Критерій культурного естетичного самовизначення полягає в готовності й умінні старшокласника до самостійного формування естетичного ставлення до дійсності, здатності орієнтуватися в культурних змінах, зберігаючи культурне коріння.

Розглядаючи культурне самовизначення як безперервний процес створення і реалізації системи уявлень індивіда про культурний простір, своє місце і зміст спілкування в ньому, вказаний критерій враховує внутрішні культурні умови й потенції саморозвитку сучасного старшокласника, складний соціокультурний контекст існування, можливості здійснення особистістю акту самовизначення під впливом мистецтва, що виражається в потребі визнання власної особистості, рівноправному спілкуванні з навколишніми і вільному естетичному самовираженні [4].

Критерій естетичного самовизначення характеризує також потенційну здатність до відповідальних дій суб' єкта за власними культурними критеріями, інтересами, поглядами [2; 34].

Його основними показниками є: 
- позитивна культурна естетична ідентифікація особистості (прийняття й визнання старшокласниками культурно- естетичних цінностей як вагоміших, усвідомлення культурноісторичних зв'язків);

- $\quad$ виявлення потреби саморозвитку та естетичного самовираження;

- залучення до естетичної діяльності (сприйняття, оцінювання і перетворення явищ дійсності й мистецтва за законами краси);

- досвід культурної діяльності, самостійна вільна художня творчість зі створення нових культурних цінностей.

Критерій готовності до міжкультурного діалогу передбачає готовність старшокласника до взаємодії з культурами різних народів на основі міжнаціонального полікультурного діалогу, що має мотиваційну, діяльнісно-поведінкову та емоційно-творчу складові. Мотиваційну готовність до діалогу складають самостійність, гнучкість, критичність мислення; діяльнісно-комунікативну складову - товариськість, діалогічність, толерантність; емоційно-творче ставлення до культури різних народів - зацікавленість, емпатія, креативність.

На думку Г. Дмитрієва, школярі повинні вміти спілкуватися з «різними в культурному відношенні людьми, правильно розуміти людські відмінності, бути толерантними, уміти стверджувати особистими справами і словами культурний плюралізм у суспільстві» [5, с. 116].

А. Джуринський зауважує, що метою полікультурної освіти і виховання є водночас «набуття знань і виховання як частина педагогічних зусиль, що забезпечують соціальну ідентифікацію особистості, відкриту іншим культурам, національностям, расам, віруванням. Мається на меті три групи педагогічних цілей, які означені поняттями плюралізм, рівність і об’єднання: пошана і збереження культурного різноманіття; підтримка рівних прав на освіту і виховання; виховання в дусі загальнонаціональних політичних, економічних, духовних цінностей. Так, толерантність - лише початок залучення до інших культур. За цим мають реалізовуватися розуміння, пошана i, нарешті, активна солідарність. Далі отримують визнання засновані на розумінні особливостей різних культур поняття: взаємодія, взаємозалежність, взаємообмін» [5, с. 41].

Готовність до міжкультурного діалогу як один із напрямів естетичного розвитку є процесом входження дитини до нового культурного простору, що орієнтує їі на вільний творчий розвиток у соціокультурному середовищі. Пізнання унікальності, неповторності кожної культури відбувається через самопізнання, самоактуалізацію особистості в результаті саморозвитку й самоорганізації, а прагнення залучитися до скарбів світової культури дозволяє розглядати культуру як систему суб'єктивних сенсів і ціннісних орієнтацій.

Основні показники: 1) усвідомлення різноманітності та цінності культур; 2) обізнаність у реаліях і традиціях культур світу; 3) розуміння взаємовпливу та взаємозбагачення культур; 4) сприйняття сучасного полікультурного світу; 5) культурна толерантність, емпатія.

Залежно від співвідношення цих критеріїв можна виокремити такі рівні естетичної вихованості:

Високий рівень (особистісна соціально-творча орієнтація) характеризується умінням адекватного сприймання естетичного об'єкта в єдності змісту і форми; обгрунтованою естетичною оцінкою 3 позиції гуманістичного естетичного ідеалу, яскраво вираженим творчим діяльнісним підходом, зацікавленістю, емпатією, креативністю; цілісним естетичним сприйняттям, у якому гармонійно поєднується інтелектуальне та емоційне.

Поданий рівень відрізняє естетичне ставлення, яке пропорційно поєднує суспільно-культурні норми й особистісну орієнтацію, подолання дисгармонії між інтелектуальним осмисленням i емоційним відгуком, безпосередність переживання i творчий характер сприйняття, оцінка авторського погляду на світ, об'єднання вищевказаного під егідою індивідуальності, усвідомлене естетичне ставлення, що виражає засвоєні школярем культурні традиції, еталони, які існують у суспільстві.

Середній рівень (культурно-нормативно оцінна орієнтація),якому властиві поглиблене, вдумливе сприйняття мистецтва i життя, абстрагування, пошук причинно-наслідкових зв'язків, зниження емоційної сфери. Для цього рівня характерна адекватність сприйняття естетичному об'єкту, проте аналіз носить словесно-логічний характер із низьким рівнем емоційності або ж яскравість та емоційність сприйняття поєднується з недостатнім рівнем аналітичного підходу. Оцінка художнього артефакту правильна, відносно самостійна, але однобічна. Старшокласник виявляє бажання брати участь у деякій художній діяльності, але через недостатність усвідомлення свого місця в культурному просторі, зацікавленість не трансформується в самостійну вільну художню творчість зі створення нових культурних цінностей.

Низький рівень (стихійна оцінна орієнтація) - неусвідомлена оцінка без співвідношення естетичних предметів i явищ із культурними еталонами, буденні висловлювання та судження. Характерними показниками є безсистемність мислення, описовість під час передачі вражень, стеження за фактами і подіями без будь-яких спроб зробити висновок або узагальнити. Учні позбавлені духовного потягу до творів мистецтва, не володіють навичками художнього сприйняття. Цей рівень характеризується недостатнім розвитком естетичного сприйняття: відсутність обгрунтованості, доказовості, оцінка відрізняється невизначеністю; невміння охарактеризувати 
естетичну своєрідність предмета, що сприймається, явища дійсності або витвору мистецтва. Рівень відзначається невираженою здатністю помічати елементи прекрасного, індиферентністю до естетичного перетворення довкілля, низьким рівнем толерантності особистості.

Сформульовані критерії та їх показники стали основою для діагностування рівнів сформованості дослідження естетичної вихованості старшокласників.

\section{Література}

1. Борев Ю. Б. Эстетика: [учебник] / Ю. Б. Борев. - М. : Высшая школа, 2002. - 511 с. 2. Газман О. Базовая культура и самоопределение личности. Базовая культура личности: теоретические и методологические проблемы / О. С. Газман // сб. науч. тр. под ред. Газманова О. С. - М. : Изд.АПН СССР, 1989. - 150 с. 3. Гачев Г. Творчество, жизнь, искусство / Г. Гачев. - М. : Детская литература, 1980. - 143 с. 4. Гінзбург М. Р. Психологическое содержание личностного самоопределения / М. Р. Гинзбург // Вопросы психологии. - 1994. № 3. - С. 43-52. 5. Джуринский А. Н. Проблемы поликультурного воспитания в зарубежной педагогике / А. Н. Джуринский // Вопросы философии. - 2007. - № 10. - С. 41-52. 6. Дмитриев Г. Д. Многокультурное образование / Г. Д. Дмитриев. - М. : Народное образование, 1999. - 208 с. 7. Липский В. Н. Эстетическая культура и личность / В.Н.Липский. - М. : Знание, 1987. - 123 с. 8. Педагогика / С. П. Баранов, Л. Р. Болотина, В. А. Сластенин и др.; под ред. С. П. Баранова и В.А. Сластенина. - М.: Просвещение, 1986. - 334 с. 9. Сластенин В. А. Педагогика [Текст]: учеб. пособие для студ. высш. пед. учеб. заведений / В. А. Сластенин, И. Ф. Исаев, В. Н. Шиянов. - М. : Академия, 2002. - 576 с. 10. Эстетическая культура и эстетическое воспитание: [книга для учит.] / сост. Г. С. Лабковская. - М. : Просвещение, 1983. - 304 с. 